\title{
Aspek-aspek Pembaruan Hukum Islam dalam Hukum Keluarga di Indonesia
}

\author{
Fitriyani \\ Dosen Fakutas Hukum dan Syariah \\ Institut Agama Islam Negeri (IAIN) Ambon \\ hj_fitriyani@yahoo.co.id
}

Abstract: Islamic law reform is essentially contrary to something that already exists (existing) then undergo a qualitative change as a product of interaction in public life It could be argued that the process of law reform Islam is seen as something autonomous, but he also interacts with other elements in society that occurred interdependent. Therefore, the concept of renewal of Islamic law requires adaptatif stance with social conditions in which it interacts. In this case, the realization of the principle of al-muhafadzah 'ala al-qadim wa al-Salih al-akhdzu bi al-jadidi al-ashlah (maintaining the old one if it is still good and accept the new or changed if it is considered better), became a necessity. Within the framework of family law reform Indonesia, Islamic law meempunyai a very important role and strategic. Said, because the family law of Islam. in addition to recognized as a source of juridical law, also has universal principles and in accordance with the personality of the Indonesian nation. In fact, sociologically Islamic family law has taken root and become law who live in the midst of the majority of Indonesian people. Renewal of Islamic law in the context of family law Indonesia includes four categories, namely; jurisprudence, fatwa, jurisprudence and legislation. 


\section{Pendahuluan}

Pembaruan hukum Islam pada dasarnya bertolak pada sesuatu yang telah ada (existing), kemudian mengalami perubahan secara kualitatif sebagai produk interaksi dalam kehidupan masyarakat. Dapat dikatakan bahwa proses pembaruan hukum Islam dipandang sebagai sesuatu yang otonom, akan tetapi ia pun berinteraksi dengan unsur lain dalam masyarakat sehingga terjadi saling bergantung. Ketika hukum Islam berinteraksi dengan kehidupan sosial masyarakat senantiasa dihadapkan pada masalah, baik yang bersifat internal maupun eksternal. Oleh karena itu, konsep pembaruan hukum Islam menuntut adanya sikap adaptatif dengan kondisi sosial masyarakat di mana ia berinteraksi. Dalam hal ini, perwujudan kaidah al-muhafadzah 'ala al-qadim al-shalih wa al-akhdzu bi al-jadidi al-ashlah (memelihara yang lama jika hal itu masih baik dan menerima yang baru atau perubahan jika hal itu dianggap lebih baik), menjadi suatu keharusan. Hal ini penting karena prilaku mukallaf yang menjadi obyeknya dipandang sebagai sesuatu yang kontinum dan senantiasa mengalami perubahan.

Dengan demikian, pembaruan hukum Islam harus dilakukan dalam memberikan respon terhadap tuntutan perubahan yang terjadi di tengahtengah masyarakat. Dikatakan demikian karena salah satu bentuk dari universalitas hukum Islam dilihat dari daya adaptabilitas dan fleksibilitas hukum Islam itu sendiri. Itu berarti bahwa pemikiran hukum Islam tidak kostan dalam satu zaman, tempat dan keadaan, melainkan senantiasa mengalami perubahan secara dinamis seiring dengan perubahan zaman, tempat dan keadaan. Hal ini sesuai dengan pendapat al-Jauziyah yang mengatakan bahwa تغير الفتاوى واختلافها بحسب تغير الازمة والامكنة والاحوال والنيات والعوائد ألماند (Perubahan ide-ide atau pemikiran hukum dan perbedaannya sesuai dengan perubahan zaman, ruang, keadaan, niat, dan kebutuhan). Bahkan lebih jauh al-Jauziyah mengatakan bahwa tidak memahami (mempertimbangkan, pen.) perubahan, merupakan kesalahan besar dalam syari'at. ${ }^{1}$

1 Lihat, Ibnu Qayyim al-Jauziyah, I'lam al-Muwaqqiin an Rab al-Alamin, Juz III, (Beirut: Dar al-Fikr, t. th.), h. 14. 
Kendatipun pembaruan hukum Islam dipandang sebagai suatu keharusan, akan tetapi perlu ditegaskan bahwa pembaruan hukum Islam yang meliputi segala bentuk muamalah diizinkan oleh syariat Islam, sepanjang tidak kontra produktif dengan jiwa dan roh hukum Islam itu sendiri. Dikatakan demikian karena hukum Islam dalam bidang muamalah hanya mengatur dan menetapkan prinsip-prinsip pokoknya secara umum, sedangkan perinciannya diserahkan kepada manusia untuk memikirkannya, dengan catatan tetap berangkat dari prinsip dasar yang dikehendaki oleh hukum Islam itu sendiri. Dalam hal ini, dapat dikatakan bahwa jiwa dan prinsip hukum Islam bersifat konstan, permanen, stabil dan tidak berubah sepanjang masa. Akan tetapi, terhadap peristiwa hukum, teknis dan cabang-cabangnya, dapat mengalami perubahan atau pembaruan sesuai dengan tuntutan zaman. ${ }^{2}$

Salah satu aspek yang sangat penting dalam kehidupan muamalah adalah masalah hukum keluarga. Dalam kaitan ini J.N.D. Anderson mengatakan bahwa hukum keluarga dianggap sebagai inti syari'at, karena bagian inilah yang oleh umat Islam dianggap sebagai pintu gerbang untuk masuk lebih jauh ke dalam wilayah agama dan masyarakat. ${ }^{3}$ Hukum keluarga sebagai bagian penting dalam hukum Islam, tidak luput dari gagasan pembaruan sebagaimana dengan bagian hukum Islam lainnya. Bahkan, pembaruan hukum keluarga Islam telah menjadi wacana yang mengglobal di seluruh dunia Islam, khususnya di Indonesia. Dalam artian bahwa pembaruan hukum Islam telah menjadi suatu isu dari gerakan modernisasi yang paling hangat dibicarakan di dunia Islam. Kendatipun demikian, dalam prosesnya tidak dapat terlepas dari berbagai aspek yang mengitari gagasan pembaruan hukum keluarga Islam.

2 Lihat, Rahmat Djatnika, Jalan mencari Hukum Islam Upaya Ke Arah Pemahaman Metodologi Ijtihad, Dalam, Amrullah Ahmad SF, Dimensi Hukum Islam Dalam Sistem Hukum Nasional, (Cet. I; Jakarta: Gema Insani Press, 1996), h. 106-107.

3 Lihat, J.N.D. Anderson, Islamic Law in Modern World, alih bahasa oleh Machnun Husain dengan judul: Hukum Islam di Dunia Modern (Cet. I; Surabaya: Amar Press, 1991), h. 42. 
Dalam kontes tersebut, paling tidak terdapat dua faktor, yaitu faktor internal dan faktor eksternal. Faktor internal adalah terjadinya perbedaan antara umat Islam sendiri dalam memaknai pembaruan hukum Islam, baik secara substantif maupun secara metodologis. Sedangkan faktor eksternal adalah kehidupan sosial masyarakat yang mengitarinya, bahkan termasuk faktor kekuasaan negara. Dengan demikian, fokus permasalahan yang akan dikaji dalam makalah ini adalah terkait dengan masalah pembaharuan hukum Islam dan aspek-aspek pembaharuan hukum Islam keluarga dalam hukum keluarga di Indonesia.

\section{Paradigma Pembaruan Hukum Islam di Indonesia}

Secara garis besarnya, hukum Islam meliputi empat bidang, yaitu: pertama, bidang ibadah, yakni merupakan penataan hubungan antara manusia dengan Allah Swt. Kedua, bidang munakahah, merupakan penataan hubungan antara manusia dalam lingkungan keluarga. Ketiga, bidang muamalah, merupakan penataan hubungan antar manusia dalam pergaulan hidup masyarakat. Keempat, bidang jinayah, merupakan penataan pengamanan dalam suatu tertib pergaulan yang menjamin keselamatan dan ketentraman dalam kehidupan masyarakat. ${ }^{4}$ Sedangkan menurut A. Jazuli, hukum Islam meliputi: bidang ibadah, bidang ahwal al-Syakhshiyah (perkawinan, kewarisan, wasiat, dan wakaf), bidang muamalah (dalam arti sempit), bidang jinayah, bidang aqdhiyah (peradilan), dan bidang siyasah (dusturiyah, maliyah, dan dauliyah). ${ }^{5}$

Pembidangan hukum Islam tersebut, sejalan dengan perkembangan pranata sosial, sebagai norma yang berfungsi untuk memenuhi kebutuhan manusia dalam kehidupan individual dan kolektif. Oleh karena itu, semakin beragam kebutuhan hidup manusia dan semakin beragam pranata sosial, maka semakin berkembang pula pemikiran ulama dan pembidangan hukum Islam pun mengalami pengembangan. Hal itu menunjukkan, terdapat korelasi positif antara perkembangan

4 Lihat, Ali Yafi, Menggagas Fikih Sosial (Cet. I; Bandung: Mizan, 1995), h. 132.

5 Lihat, A. Jazuli, Ilmu Fiqh: Sebuah Pengantar (Cet. I; Bandung: Orba Shakti, 1991), h. 54 . 
pranata sosial dengan pemikiran ulama secara sistematis. Atau sebaliknya, penyebarluasan produk pemikiran ulama yang mengacu kepada firman Allah melahirkan berbagai pranata sosial. ${ }^{6}$

Hukum Islam yang termaktub di dalam ayat-ayat ahkam, hadishadis ahkam, dan terutama di dalam kitab-kitab fikih dipahami terus mengalami perkembangan dan pengembangan. Dalam proses pengembangan, hukum Islam mengalami internalisasi ke dalam berbagai pranata sosial yang tersedia di dalam masyarakat. Terjadi proses alokasi hukum Islam, dalam dimensi syariah ke dalam pranata sosial, menjadi landasan dan memberi makna serta arah dalam kehidupan masyarakat Islam Indonesia. Hasil dari proses pengembangan hukum Islam yang terjadi dalam rentang waktu berabad-abad, berkembang berbagai pranata sosial yang bercorak keislaman. ${ }^{7}$

Pranata-pranata sosial dapat dilihat dari dua sudut pandang, yaitu: pertama, ia merupakan aktualisasi hukum Islam yang tertumpu kepada interaksi sosial yang mempola setelah mengalami pergumulan dengan kaidah-kaidah lokal yang dianut oleh masyarakat Indonesia yang majemuk. Dalam pergumulan itu, terjadi adaptasi dan modifikasi antara hukum Islam dengan kaidah lokal. Dengan perkataan lain bahwa proses sosialisasi dan institusionalisasi hukum Islam terjadi dalam hubungan timbal balik dengan kaidah-kaidah lokal yang dianut. Selain itu, terjadi intervensi hukum barat terutama sejak masa penjajahan Belanda.

Kedua, pranata-pranata sosial merupakan perwujudan interaksi sosial di dalam masyarakat Islam untuk memenuhi kebutuhan hidup mereka. Interaksi sosial itu berpatokan dan mengacu kepada keyakinan (kesepakatan tentang benar dan salah), nilai (kesepakatan tentang baik dan buruk), dan kaidah (kesepakatan tentang yang mesti dilakukan dan yang mesti ditinggalkan), yang dianut oleh mereka. Ia merupakan perwujudan amal shaleh sebagai ekspresi keimanan dalam interaksi sosial. ${ }^{8}$

${ }^{6}$ Lihat, Cik Jasan Bisri, Hukum Islam Dalam Tatanan Masyarakat Indonesia (Cet. I; Jakarta: Logos, 1998), h. 115.

7 Lihat, Ibid., h. 116.

8 Lihat, Ibid., h. 117-118. 
Dalam kehidupan masyarakat Islam Indonesia dewasa ini, dikenal berbagai pranata sosial yang bercorak keislaman. Pranata-pranata sosial meliputi berbagai bidang kehidupan, yang senantiasa mengalami perkembangan dari waktu ke waktu. Ada pranata yang amat dekat dengan keyakinan yang dianut, sehingga memiliki tingkat kepekaan yang sangat tinggi, seperti pranata peribadatan, pranata kekerabatan, dan pranata pendidikan. Ada pula pranata sosial yang relatif agak jauh dari keyakinan, sehingga relatif luwes atau netral, seperti pranata ekonomi dan pranata keilmuan, sehingga proses adaptasinya relatif longgar dan labelnya sebagai hukum Islam bersifat luwes. Selanjutnya pranata-pranata sosial mengalami kongkretisasi dalam struktur masyarakat, dalam bentuk berbagai organisasi sosial sebagai wahana untuk memenuhi kebutuhan hidup secara kolektif dan terencana. Kenyataan itu menunjukkan bahwa di dalam masyarakat terjadi penyerapan produk teknologi sosial (pengorganisasian masyarakat) mutakhir, dan dapat dijadikan saluran untuk mengaktualisasikan hukum Islam di dalam kehidupan nyata. ${ }^{9}$

Dengan demikian, pembaruan hukum Islam sebagai aktualisasi perintah Allah mempunyai beragam bentuk dan mencakup beragam pranata sosial. Oleh karena itu, pembaruan hukum Islam di Indonesia terpola pada internalisasi hukum Islam ke dalam pranata-pranata sosial atau sebaliknya pranata sosial terinternaliosasi ke dalam hukum Islam. Pada konteks ini, tampak relasi yang saling mendukung antara hukum Islam dan pranata sosial.

Dalam konteks tersebut, pembaruan hukum Islam di Indonesia meliputi empat kategori, yaitu:

\section{Fikih}

Salah satu wujud hukum Islam yang sistematis dan rinci adalah fikih. ${ }^{10}$ Secara garis besarnya fikih meliputi empat bidang, yaitu: per-

\footnotetext{
9 Lihat, Ibid., h. 118.

${ }^{10}$ Secara etimologis fikih berarti paham yang mendalam. Sedangkan menurut Hasbi Ash-Shiddiqy, fikih adalah ilmu syariat. Al-Amidi mendefenisikan fikih sebagai
} 
tama, ibadah merupakan penataan hubungan antara manusia dengan Tuhan. Kedua, bidang muakahat yang merupakan penataan hubungan antar manusia dalam lingkungan keluarga. Ketiga, bidang muamalah merupakan penataan hubungan antar manusia dalam pergaulan kemasyarakatan.keempat, bidang jinayah merupakan penataan pengamanan dalam suatu tertib pergaulan yang menjadi keselamatan dan ketenteraman dalam hidup bermasyarakat. ${ }^{11}$

Fikih sebagai produk pemikiran hukum Islam, baru berkembang pada masa sahabat sepeninggal Rasulullah. Hal itu disebabkan oleh karena pada masa kenabian karena setiap persoalan yang ada dengan mudak dapat diselesaikan oleh nabi sendiri melalui wahyu dan sabdasbadanya (baca; hadis). Muncul dan berkembangnya kajian-kajian fikih disebabkan oleh muncul persoalan-persoalan akibat semakin meluasnya wilayah Islam dan semakin besarnya jumlah umat Islam dengan latar belakang etnis dan kultur yang berbeda. ${ }^{12}$ Oleh karena masalahmasalah yang muncul itu belum pernah dialami oleh Rasulullah dan tidak terdapat nash secara jelas dan tegas tentang hal itu, maka para sahabat dan generasi berikutnya dituntut untuk berpikir dalam menyelesaikan masalah-masalah yang ada.

ilmu tentang seperangkat hukum-hukum syara' yang bersifat furu'iyyah yang didapat melalui penalaran atau istidlal. Dalam banyak hal, fikih selalu diidentikkan dengan hukum Islam. Pengidentikkan ini telah melahirkan suatu kekeliruan dalam penerapannya. Dikatakan demikian karena pada dasarnya kedua istilah ini memiliki makna yang berbeda, fikih hanyalah salah satu bagian dari hukum Islam. Oleh Abd. Wahab Khallaf, fikih adalah pengetahuan tentang hukum-hukum syari'ah Islam mengenai perbuatan manusia yang diambil dari dalil-dalil yang detail. Sedangkan dalam proses perkembangannya fikih lebih dikesankan sebagai produk pemikiran manusia. Dalam istilah lain, fikih merupakan hasil interpretasi manusia dari dalil-dalil hukum, sedangkan hukum Islam atau syariah lebih dikesankan sebagai hukum-hukum qath'iy yang tidak interpretatif. Lihat, M. Hahya Harahap, Informasi Materi Kompilasi Hukum Islam : Mempositifkan Abstraksi Hukum Islam, dalam Cik Hasan Bisri (Peny.), Kompilasi Hukum Islam dan Peradilan Agama dalam Sistem Hukum Nasional (Cet. II; Jakarta : Logos Wacana Ilmu, 1999), h. 21 dan 23. Lihat pula, Ahmad Hanafi, Sejarah dan Pengantar Hukum Islam (Cet. IV; Jakarta : Bulan Bintang, 1986), h. 9.

${ }^{11}$ Lihat, Ali Yafie, Fikih Sosial (Cet. I; Jakarta : Logos Wacana Ilmu, 1994), h. 132.

${ }^{12}$ Lihat, Dede Rosdaya, Op.cit, h. 5. 
Sekaitan dengan hal tersebut, fikih sebagai produk pemikiran hukum Islam di Indonesia, karakteristiknya sangat kental dengan kepribadian Arab. Hal itu disebabkan oleh karena jaringan intelektual para fuqaha Indonesia terlalu Arab oriented. Kondisi seperti ini berlangsung hingga paro pertama abad ke 20. ${ }^{13}$ Pada konteks ini, Hasbi Ash-Shiddiqy mengatakan bahwa terdapat bagian-bagian fikih kaum muslimin Indonesia yang didasarkan pada urf timur tengah yang tidak sesuai dengan rasa kesadaran hukum masyarakat Indonesia yang melembaga dalam hukum adat. Atas dasar itulah sehingga fikih kurang mendapat sambutan hangat dari masyarakat Indonesia, karena dianggap tidak sesuai dengan kepribadian bangsa Indonesia. ${ }^{14}$

Keterasingan fikih itu sebagaimana yang disinyalir oleh Hasbi ashShiddiqy tersebut antara lain juga disebabkan oleh pandangan fikih yang terlalu formalistik. Kecenderungan fikih yang demikian menjadikannya sebagai paradigma kebenaran ortodoks, di mana semua realitas tunduk pada kebenaran fikih. Penekanan yang terlalu berlebihan pada formalisme dan kecenderungan melakukan teologisasi fikih, menyebabkan fikih Indonesia seolah-olah menjauhi diri dari realitas sosial dan kultur masyarakat yang menjadi obyeknya. ${ }^{15}$ Oleh karena itu, sudah saatnya dipikirkan upaya untuk menggeser paradigma fikih ortodoksi kepada paradigma fikih berwawasan sosial-budaya, yaitu melakukan pembaruan paradigma fikih yang ramah dengan kultur dan budaya bangsa

13 Lihat, Marzuki Wahid dan Rumadi, Fikih Mazhab Negara (Cet. I; Yogyakarta: LkiS, 2001), h. 129.

${ }^{14}$ Selengkapnya Hasbi Ash-Shiddiqy mengatakan "fikih yang berkembang dalam masyarakat kita sekarang, sebagiannya adalah fikih Hijazi yaitu fikih yang terbentuk atas dasar adat istiadat yang berlaku di Hijaz atau fikih Misryi, yaitu fikih yang terbentuk atas dasar adat istiadat dan kebiasaan di Mesir, atau fikih Hindy yaitu fikih yang terbentuk berdasarkan adat kebiasaan yang berlaku di India. Selama ini kita belum menunjukkan kemampuan untuk berijtihad untuk mewujudkan fikih yang sesuai dengan kepribadian Indonesia, karena itu kadang-kadang kita paksakan fikih Hijazi atau fikih Misry dan lain-lain untuk berlaku di Indonesia atas dasar taklid. Lihat, Hasbi Ash-Shiddiqy, Syariat Islam Menjawab Tantangan Zaman (Jakarta: Bulan Bintang, 1966), h. 41-42.

${ }^{15}$ Lihat, Marzuki Wahid dan Rumadi, Op.cit., h. 130-131. 
Indonesia dengan tetap berpegang pada prinsip-prinsip universal hukum Islam, yaitu memelihara agama, akal, jiwa, kehormatan dan harta. Jika paradigma pertama memperlihatkan hitam-putih dalam memandang realitas, maka yang kedua memperlihatkan watak yang bernuansa kultural. Kiranya gagasan Gus-Dur tentang pribumisasi Islam patut mendapat sambutan dan kajian lebih jauh dalam upaya pembaruan fikih sebagai produk pemikiran hukum Islam yang berwawasan budaya yang mempertimbangkan kearifan-kearifan lokal.

\section{Fatwa}

Fatwa adalah hasil ijtihad seorang mufti sehubungan dengan peristiwa hukum yang diajukan kepadanya. Produk pemikiran hukum Islam dalam kategori fatwa, di antara cirinya ialah bersifat kasuistik, karena merupakan respon atau jawaban atas pertanyaan yang diajukan oleh peminta fatwa. Berbeda dengan putusan pengadilan, fatwa tidak mempunyai daya ikat dan daya paksa, dalam arti bahwa yang meminta fatwa tidak harus mengikuti isi atau hukum yang diberikan kepadanya. Demikian pula masyarakat luas tidak harus terikat dengan fatwa itu, karena fatwa seorang ulama di suatu tempat bisa saja berbeda dengan fatwa ulama lain di tempat yang sama. Biasanya fatwa cenderung bersifat dinamis karena merupakan respon terhadap perkembangan baru yang sedang dihadapi oleh orang atau kelompok yang meminta fatwa. Isi suatu fatwa belum tentu dinamis, akan tetapi sikap responnya itu sekurang-kurangnya dapat dikatakan dinamis. Meskipun fatwa itu dikeluarkan secara kasuistik, namun sejumlah fatwa dari ulama besar atau lembaga keagamaan dan hukum telah dibukukan, akan tetapi sistematikanya tetap berbeda dengan fikih. ${ }^{16}$

Dalam sejarah, pelaksanaan pemberian fatwa dimulai sejak agama Islam meluaskan wilayah pengaruhnya pada abad ke 7 dan ke 8. Kaum muslimin menghadapi berbagai persoalan yang membutuhkan penyelesaian hukum terhadap persoalan-persoalan baru dengan cepat. Bagi

\footnotetext{
${ }^{16}$ Lihat, Muh. Atho Mudzhar, Fatwa-Fatwa Majelis Ulama (Cet. I; Jakarta: INIS, 1993), h. 3.
} 
mereka yang tinggal di kota-kota besar, umumnya mereka menyelesaikan persoalan-persoalan yang dihadapi melalui lembaga peradilan atau hakim-hakaim yang dapat menyelesaian persoalannya. Akan tetapi bagi meraka yang tinggal jauh dari kota-kota besar, baisanya dalam menyelesaikan persoalannya cukup bertanya atau meminta fatwa kepada orang yang dianggap pintar. ${ }^{17}$

Di Indonesia, pembaruan hukum Islam dalam kategori fatwa dilakukan oleh organisasi-organisasi kemasyarakatan seperti NU, MUI, Muhammadiyah dan Persis. ${ }^{18}$ Masing-masing organisasi mempunyai lembaga khusus yang melakukan pembaruan hukum Islam dalam bentuk fatwa. Dalam lingkungan NU adalah pembaruan hukum Islam dalam bentuk fatwa dilakukan Mejelis Syuriah dan majelis Ahlu al-Hall wa al-Aqdi, di lingkungan MUI adalah Komisi Fatwa, di lingkungan Muhammadiyah adalah Majelis Tarjih dan di lingkungan Persis adalah Dewan Hisbah. Pembaruan hukum Islam melalui organisasi ini memiliki kegunaan praktis terutama bagi yang membutuhkannya, baik oleh pmerintah maupun oleh para pemimpin dan anggota masyarakat, pada gilirannya fatwa dapat menjadi acuan dalam penerapan hukum Islam. ${ }^{19}$

\section{Putusan hakim / Peradilan Agama (Yurisprudensi)}

Dalam kepustakaan hukum anglo saxon perkataan yuisprudensi mengandung arti yang lebih luas dari perkataan yurisprudensi dalam hukum Eropa Kontinental. Di dalam kepustakaan anglo saxon, yurisprudensi selain bermakan hukum (dalam putusan) hakim, juga bermakna filsafat hukum dalam ilmu hukum. Sedangkan dalam kepustakaan Eropa kontinental dan dalam kepustakaan hukum Indonesia, yang disebut yurisprudensi adalah kumpulan keputusan Mahkamah Agung

${ }^{17}$ Lihat, Muh. Atho Mudzhar, Fatwa-Fatwa Majelis Ulama (Jakarta: INIS, 1993), h. 2.

${ }^{18}$ Selain itu, fatwa dapat pula dilakukan oleh pengadilan dalam lingkungan peradilan Agama sebelum berlakunya Undang-Undang No. 7 tahun 1989, khususnya di bidang kewarisan, hibah, wasiat, harta bersama dan kedudukan anak.

${ }^{19}$ Lihat, Cik hasan Bisri, Aspek-Aspek Sosiologis ... Op.cit. h. 130-131. 
(dan Pengadilan Tinggi) mengenai perkara tertentu berdasarkan pertimbangan (kebijaksanaan) hakim sendiri yang diikuti sebagai pedoman oleh lain dalam memutus perkara yang sama atau hampir sama. ${ }^{20}$

Pembaruan produk pemikiran hukum Islam melalui yurisprudensi dipandang perlu dan baik. Dikatakan demikian karena yurisprudensi selain menggambarkan keadilan yang tumbuh dan berkembang dalam masyarakat, juga selaras dengan kesadaran hukum masyarakat muslim Indonesia, dengan catatan bahwa hakaim peradilan Agama yang membuat yurisprudensi itu, selaim paham benar tentang hukum Islam, juga memperhatikan dengan sungguh-sungguh nilai-nilai hukum pada umumnya yang terdapat dalam masyarakat.

Lebih jauh dapat dikatakan bahwa pembaruan hukum Islam melalui yurisprudensi dianggap sebagai sesuatu yang baik, didasarkan atas beberapa alasan bahwa putusan hakim (yurisprudensi) mempunyai kekuatan mengikat, terutama kalau putusan itu dikeluarkan oleh Pengadilan Tinggi atau Mahkamah Agung. ${ }^{21}$ Di samping itu, yurisprudensi secara psikologis dapat diterima oleh masyarakat karena ia lahir dari suatu perkara yang secara langsung terjadi dalam masyarakat. Itu artinya bahwa yurisprudensi lebih menyentuh masalah-masalah praktis dalam tatanan sosial kemasyarakatan.

Dalam konteks tersebut, yurisprudensi sebagai produk pemikiran hukum Islam dapat dikatakan sangat dinamis karena merupakan respon terhadap perkara-perkara nyata yang dihadapi masyarakat. Keputusankeputusan peradilan Agama memang tidak meliputi semua aspek pemikiran hukum Islam sebagaimana halnya dengan fikih, akan tetapi darisegi kekuatan hukumnya ia lebih mengikat terutama bagi pihakpihak yang telah berperkara.

${ }^{20}$ Lihat, Muhammad Daud Ali, Hukum Islam dan Peradilan Agama: Kumpulan Tulisan (Cet. I; Jakarta : raja Grafindo Persada, 1997), h. 358.

${ }^{21}$ Lihat, Ibid, h. 360. 


\section{Perundang-Indangan}

Peraturan perundang-undangan sebagai salah satu wujud pembaruan hukum Islam, seperti halnya dengan yurisprudensi atau putusan pengadilan ia bersifat mengikat. Bahkan daya ikatnya lebih luas dalam masyarakat, karena tidak hanya pada pihak-pihak tertentu, akan tetapi juga seluruh masyarakat yang ada di wilayah hukumnya. Unsur-unsur yang terlibat dalam perumusan perundang-undangan tidak terbatas pada golongan ulama (fuqaha) saja, akan tetapi juga melibatkan unsurunsur lain dalam masyarakat seperti cendekiawan, politisi dan lainlain. Masa berlakunya suatu Undang-Undang, berlangsung sampai ada peraturan perundang-undangan baru yang menggantikannya. ${ }^{22}$

Di antara produk pemikiran hukum Islam yang telah diakomodasi dalam kategori peraturan perundang-undangan antara lain; UndangUndang Nomor 1 Tahun 1974 tentang perkawinan, Instruksi Presiden Nomor 1 Tahun 1991 tentang Kompilasi Hukum Islam yang mengatur tentang kewarisan, perkawinan, perwakafan, hibah, sadakah dan wasiat, dan lain-lain. Sebagai produk pemikiran hukum Islam, undang-undang memberikan sanksi hukum terhadap orang yang melakukan pelanggaran. Sebagaimana produk kolektif, Undang-Undang memiliki daya ikat yang lebih luas dari keputusan pengadilan. Dalam hal ini yang terpenting harus dimiliki oleh undang-Undang sebagai produk pemikiran hukum Islam adalah kualitas yang tinggi dan dapat mencerminkan realitas hukum yang tumbuh dan berkembang dalam masyarakat.

Terlepas dari perdebatan mengenai legitimasi yuridis Kompilasi Hukum Islam (KHI), terdapat beberapa ketentuan hukum yang dikategorikan sebagai pembaruan hukum keluarga Islam di Indonesia, antara lain: ta'lik talak yang terdapat pada pasal 45 , pengaturan tentang harta bersama atau gono gini pada pasal 85-97, ketentuan tentang ahli waris pengganti untuk cucu yatim yang terdapat pada pasal 185, ketentuan tentang wasiat wajibah untuk anak dan orang tua angkat yang terdapat pada pasal 209, ketentuan tentang harta hibah sebagai warisan yang ter-

\footnotetext{
${ }^{22}$ Lihat, Muhammad Atho Mudzhar, Op.cit., h. 3.
} 
dapat pada pasal $221 .^{23}$

Dalam kaitannya dengan hal tersebut, pembaruan hukum Islam di Indonesia dilakukan dalam dua jalur, yaitu jalur struktural dan kultural. Jalur struktural pembaruan hukum Islam dihadapkan pada kekuasaan Negara. Hal ini berarti bahwa pembaruan hukum Islam dilakukan melalui intervensi kekuasaan negara. Intervensi negara terhadap pembaruan hukum Islam terdapat dua keniscayaan, yaitu boleh jadi menguntungkan dan boleh jadi merugikan. Sedangkan pembaruan hukum Islam melalui jalur kultural, dilakukan oleh lembaga-lembaga keagamaan, seperti NU, Muhammadiyah, MUI, dan lain-lain.

\section{Aspek-Aspek Pembaruan Hukum Keluarga Islam di Indonesia}

Pembaruan hukum keluarga Islam merupakan kebutuhan yang harus segera direspon sebagai upaya memberikan jawaban terhadap problema kontemporer. Formulasi hukum keluarga Islam yang tertuang dalam kitab-kitab fikih bukan rumusan baku yang tidak boleh berubah, melainkan harus dipandang sebagai penafsiran atau rumusan para ulama pada zamannya yang membutuhkan kritisisme sesuai dengan tuntutan perubahan. Oleh karena itu, hukum keluarga Islam harus senantiasa ditafsir agar responsif dengan persoalan umat tanpa harus kehilangan prinsip dasarnya. Hal ini penting agar hukum keluarga Islam tidak mengalami fosilisasi), dan pada gilirannya akan kehilangan aktualitanya dan ditinggalkan oleh umat Islam sendiri.

Ketidaksanggupan dan kebancian ahli hukum Islam memberikan jawaban terhadap problem kontemporer yang muncul di tengah-tengah masyarakat, dikhawatirkan suatu ketika daya adaptability dan responsibility hukum keluarga Islam dipertanyakan oleh umat Islam. Ini suatu keniscayaan jika umat Islam terus terpasung dalam paradigma ortodoksi yang tidak sesuai dengan perkembangan kemodernan. Indikasi

${ }^{23}$ Lihat, Mahsun Fuad, Hukum Islam Indonesia: dari Nalar Partisipatoris Hingga Emansipatoris, (Cet. I; Yogyakarta: LKiS, 2005), h. 271. 
dari kecenderungan ini adalah adanya upaya kalangan muslim sekuler yang mengadopsi sistem hukum keluarga Barat secara mentah-mentah untuk diterapkan bagi umat Islam.

Dalam konteks pembaruan hukum Islam dalam hukum keluarga di Indonesia, menampakkan potret pembaruan yang unik sekaligus problematik. Dikatakan demikian karena di Indonesia berlaku tiga sistem hukum, yaitu hukum adat, hukum Islam dan hukum Barat. Ketiga sistem hukum ini, menurut Hooker tidak ada satupun sistem hukum yang saling menyisihkan. Di lain pihak, kesamaan derajat berlakunya ketiga sistem hukum ini tidak selamanya berjalan dalam jalur yang searah. Akan tetapi, pada situasi dan kondisi tertentu kadangkala ketiga sistem hukum ini berada dalam konflik. ${ }^{24}$ Konflik ketiga sistem hukum yang berlaku di Indonesia, pada akhirnya melahirkan ketegangan. Ketegangan yang terjadi antara ketiganya pada gilirannya menjadi problem yang serius dalam pembaruan hukum Islam di Indonesia.

Dengan demikian, pembaruan hukum Islam dalam hukum keluarga di Indonesia tidak tunggal dan berdiri sendiri. Akan tetapi, selalu konfiguratif dengan aspek-aspek yang mengitarinya. Aspek-aspek yang terkait dengan pembaruan hukum keluarga di Indonesia, antara lain:

\section{Aspek Material}

Setelah bangsa Indonesia menyatakan kemerdekaannya pada 17 Agustus 1945, pembaruan materi hukum mulai dilakukan. Hal ini dimaksudkan untuk mengganti hukum warisan kolonial Belanda yang bertentangan dengan konstitusi Negara Indonesia merdeka. Menurut Hazairin, setelah proklamasi kemerdekaan Indonesia dan UUD 1945 dijadikan sebagai konstitusi Negara, maka semua peraturan perundangan-undangan Hindia Belanda tidak berlaku lagi. ${ }^{25}$ Dengan demikian,

${ }^{24}$ Lihat, Imam Syaukani, Rekonstruksi Epistemologi Hukum Islam dan Relevansinya dengan Pembangunan Hukum Nasional, (Cet. I; Jakarta: Raja Grafindo Persada, 2006), h. 88 .

${ }^{25}$ Lihat, Ibid., h. 81. 
pembaruan materi hukum di Indonesia dimaksudkan untuk mengganti produk-produk hukum yang diwariskan oleh pemerintahan kolonial Belanda yang tidak sesuai lagi dengan prinsip-prinsip yang terkandung dalam Pancasila dan Undang-Undang Dasar 1945. Hal ini penting karena beberapa produk hukum kolonial Belanda yang sampai saat ini tetap berlaku sudah tidak sesuai lagi dengan prinsip-prinsip dasar negara Indonesia yang merdeka.

Dalam kerangka pembaruan hukum keluarga Indonesia, hukum Islam meempunyai peran yang sangat penting dan strategis. Dikatakan demikian karena hukum keluarga Islam, di samping diakui sebagai sumber hukum secara yuridis, juga mempunyai prinsip-prinsip yang universal serta sesuai dengan kepribadian bangsa Indonesia. Bahkan, secara sosiologis hukum keluarga Islam telah mengakar dan menjadi hukum yang hidup di tengah-tengah mayoritas masyarakat Indonesia.

Realitas hukum Islam sebagai sumber hukum di Indonesia tersebut, menempatkannya pada posisi yang eksistensial dalam konteks pembaruan materi hukum keluarga. Paling tidak, didukung oleh dua argumen, yaitu: pertama, hukum keluarga Islam dibangun di atas prinsip-prinsip universal, sehingga memungkinkan diterjemahkan secara substantif dalam pembaruan sistem hukum keluarga Indonesia. Itu berarti bahwa nilai-nilai substansial hukum keluarga Islam mengilhami pembaruan hukum keluarga di Indonesia, seperti beberapa pasal dalam Undang-Undang Nomor 1 Tahun 1974 tentang Perkawinan, PP No. 9 tahun 1975, PP No. 10 Tahun 1983 tentang Izin Perkawinan dan Peceraian Bagi Pegawai Negeri Sipil, serta No. 45 Tahun 1983 tentang Izin Perkawinan dan Perceraian Pegawai Negeri Sipil.

Kedua, pembaruan materi hukum keluarga Islam dalam sistem hukum keluarga di Indonesia, dapat dilakukan dengan menetapkan materi hukum keluarga Islam sebagai peraturan perundang-undangan yang berlaku secara positif. Dalam artian bahwa pembaruan materi hukum Islam sebagai hasil pemikiran ulama secara kolektif (jama'i) ditetapkan sebagai hukum positif, seperti Inpres No. 1 Tahun 1991 tentang Kompilasi Hukum Islam. Bahkan, pembaruan materi hukum 
keluarga Islam dapat dilakukan melalui ijtihad individual dan diajukan untuk ditetapkan sebagai peraturan perundang-undangan untuk mengganti beberapa materi hukum yang telah berlaku, seperti yang dilakukan oleh Munawir Sjadzali melalui gagasan reaktualisasi hukum Islam dan Musda Mulia melalui Counter of Legal Draft KHI.

\section{Aspek Metodologis}

Pembaruan hukum Islam dalam konteks hukum keluarga di Indonesia, bukan persoalan yang mudah. Paling tidak, dapat dilihat dari dua aspek, yaitu:

a. Kondisi obyektif masyarakat Indonesia yang pluralistik harus menjadi salah satu variabel pertimbangan. Hal ini penting untuk menghindari pembaruan hukum Islam yang kontra produktif sehingga merugikan umat Islam sendiri.

b. Pembaruan hukum yang dilakukan harus memperhatikan aspek metode perumusan hukum Islam dalam kontek pembaruan hukum keluarga Indonesia. Hal ini dimaksudkan agar formulasi hukum Islam yang dirumuskan tidak bertentangan dengan kesadaran dan karakteristik hukum nasional. ${ }^{26}$

Dalam konteks pembaruan hukum Islam, aspek metodologi dipandang sebagai faktor yang menentukan wujud hukum (hasil ijtihad) yang dilakukan. Oleh karena itu, dalam kerangka pembaruan hukum keluarga Islam di Indonesia yang sesuai dengan kesadaran hukum masyarakat dan sesuai dengan karakteristik hukum nasional, dapat digunakan beberapa pendekatan, yaitu:

\section{a. Pendekatan Historis}

Pendekatan historis dimaksudkan untuk mengetahui latarbelakang sejarah suatu produk hukum. Penerapan pendekatan historis dalam pembaruan hukum keluarga di Indonesia dapat dilihat pada ketentuan pasal 2 ayat 2 UU No. 1 Tahun 1974 tentang Perkawinan dan pasal 6

\footnotetext{
${ }^{26}$ Lihat, Ibid., h. 251.
} 
ayat 1 dan 2 KHI yang mengatur tentang ketentuan pencatatan perkawinan. Dalam kitab-kitab fikih klasik tidak ditemukan ketentuan tentang pencatatan perkawinan. Menurut Ahmad Rofiq bahwa tidak ditemukannya ketentuan pencatatan perkawinan dalam kitab-kitab fikih klasik karena pada waktu itu tingkat amanah kaum muslimin masih tinggi, sehingga kemungkinan penyelewengan perkawinan relatif kecil. ${ }^{27}$ Dengan demikian, seiring dengan perkembangan masyarakat yang semakin modern dan semakin kompleksnya problema masyarakat, maka ketentuan pencatatan perkawinan menemukan vitalitasnya.

\section{b. Pendekatan Maslahah}

Tingkat kemaslahatan suatu rumusan pembaruan hukum keluarga Islam di Indonesia, idealnya dijadikan sebagai ruh dari setiap ketentuan hukum. Oleh karena itu, ketentuan pencatatan perkawinan dipandang sebagai prestasi brilian para pakar hukum Islam di Indonesia. Dikatakan demikian karena pencatatan perkawinan mengandung nilai kemaslahatan yang tinggi dan merupakan solusi hukum atas merebaknya perkawinan di bawah tangan (baca; nikah sirri).$^{28}$ Dengan demikian, berdasarkan pertimbangan maslahat dapat dikatakan bahwa perkawinan di bawah tangan adalah tidak sah karena di samping bertentangan dengan ketentuan hukum positif Indonesia juga bertentangan ruh syari'at.

\section{c. Pendekatan Realitas Sosial}

Pendekatan realitas sosial secara konseptual dimaknai sebagai upaya melakukan pembaruan hukum dengan menghadirkan pendekatan realitas sosial dan pendekatan lainnya secara simultan dalam merumuskan (istinbath) hukum. Artinya bahwa dalam kerangka pembaruan hukum keluarga Islam, realitas sosial menjadi salah satu variabel dalam proses analisis atau penemuan hukum sehingga suatu hukum tidak hanya diderivikasi dari teks. Penerapan pendekatan realitas empiris dalam pembaruan hukum keluarga di Indonesia dapat dilihat pada

\footnotetext{
${ }^{27}$ Lihat, Ahmad Rofiq, Pembaharuan Hukum Islam di Indonesia, (Cet. I; Jakarta: Raja Grafindo Persada, 1995), h. 106-107

${ }^{28}$ Lihat, Imam Syaukani, op.cit., h. 255.
} 
beberapa ketentuan hukum dalam KHI, seperti ketentuan harta orang tua yang dihibahkan kepada anaknya dan setelah orang tua meninggal harta hibah tersebut diperhitungkan sebagai warisan bagi anak yang bersangkutan. Ketentuan yang demikian tidak ditemukan dalam literatur fikih klasik dan hanya ditemukan dalam hukum adat sebagai realitas sosial.

\section{Aspek Sosiologis}

Dalam konteks pembaruan hukum, aspek sosiologis yang senantiasa mengalami perkembangan dari waktu ke waktu dipandang sebagai salah aspek yang mengiringi proses pembaruan hukum. Aspek-aspek sosiologis yang mengiringi pembaruan hukum Islam dalam hukum keluarga di Indonesia, antara lain:

1. Pranata kekerabatan berfungsi sebagai pemenuhan kebutuhan pemeliharaan dan pengembangan keturunan (reproduksi). Juga untuk memelihara dan mengembangkan kebudayaan yang dianut secara kolektif. Untuk memenuhi kebutuhan itu dilakukan penataan hubungan antar individu di dalam lingkungan keluarga, sebagai organisasi sosial terkecil. Pranata itu mengalokasikan nilai dan kaidah al-ahwal al-syakhshiyah, yang berkenaan dengan penerimaan anggota keluarga baru melalui tahapan pelamaran dan perkawinan; hak dan kewajiban suami istri dalam kehidupan keluarga; pengaturan kelahiran; pengasuhan dan pendidikan anak; pengaturan harta kekayaan perkawinan; perceraian; dan pengoperalihan hak-hak pemilikan harta apabila anggota keluarga meninggal dunia (perihal kewarisan). ${ }^{29}$

\footnotetext{
${ }^{29}$ Di dalam masyarakat bangsa Indonesia dewasa ini fungsi-fungsi keluarga semakin berkembang, diantaranya fungsi keagamaan, yang mendorong dikembangkannya keluarga dan seluruh anggota nya menjadi insan-insan agamis yang penuh iman dan taqwa kepada Tuhan Yang Maha Esa. Pengaturan kehidupan keluarga dalam hal ini perkawinan, diatur menurut ketentuan peraturan perundang-undangan yaitu undangundang Nomor 1 tahun 1974 tentang perkawinan dan berbagai peraturan pelaksanaannya. Alokasi hukum Islam di dalam peraturan itu sangat besar, bahkan dominan.
} 
2. Pranata pendidikan, berfungsi sebagai pemenuhan kebutuhan dalam mensosialisasikan keyakinan, nilai-nilai dan kaidah-kaidah yang dianut oleh suatu generasi kepada generasi berikutnya. Selanjutnya, sosialisasi itu meliputi informasi-informasi baru dan berbagai aspek yang dibutuhkan di dalam kehidupan masyarakat. Untuk memenuhi kebutuhan tersebut, dilakukan pengaturan yang berkenaan dengan jalur, jenis dan jenjang pendidikan. Dengan demikian, tingkat pendidikan menjadi faktor yang menentukan dalam proses pembaruan hukum di Indonesia.

3. Pranata keilmuan, berfungsi sebagai pemenuhan kebutuhan dalam mengembangkan pemahaman terhadap ayat-ayat Allah, yaitu ayatayat qawliyah dan ayat-ayat kawniyah. Ayat-ayat al-Qur'an yang pertama kali diterima Rasulullah Saw. (S. al-Alaq: 1-5) memberikan petunjuk tentang keharusan "membaca" ciptaan Allah Swt. Untuk memenuhi kebutuhan itu dilakukan penataan tentang sumber, substansi, metode, dan kegunaan hasil pemahaman tersebut. Hasil pemahaman itu disebarluaskan dalam berbagai karya ilmiah di antaranya dalam kitab-kitab fikih dalam berbagai aliran pemikiran (mazhab). ${ }^{30}$

4. Pranata politik, berfungsi sebagai pemenuhan medium dalam melakukan pembaruan hukum keluarga di Indonesia melalui artikulasi politik di dalam kehidupan masyarakat, berbangsa dan bernegara.

${ }^{30}$ Adanya berbagai mazhab fikih, umpamanya menunjukkan bahwa di dalam masyarakat Islam Indonesia dikenal pranata keilmuan, dengan ulama sebagai sentralnya. Ia merupakan pengembangan suatu kegiatan intelektual yang dilakukan dengan menggunakan metode dan pendekatan tertentu secara konsisten. Kegiatan itu berlangsung secara berkelanjutan, yang kemudian dikalangan antropolog dikenal sebagai tradisi tradisi besar (great tradition). Pusat-pusat pengkajian tumbuh dan berkembang terutama dalam lingkungan pesantren, perguruan tinggi, dan lembaga swadaya msyarakat. Demikian halnya, pengkajian dilakukan dalam lingkungan organisasi kemasyarakatan, misalnya dalam lingkungan MUI dilaksanakan oleh Komisi Pengkajian Masalah Keagamaan. Oleh karena itu, dikalangan umta Islam Indonesia dikenal pranata keulamaan sebagai simbole pewaris para nabi. Ulama, sebagai kelompok elite dalam komunitas Islam di Indonesia memiliki karakteristik sendiri, serta memiliki peranan yang sangat penting dalam perkembangan masyarakat bangsa Indonesia. 
Artikulasi politik itu dilakukan melalui infra dan supra struktur politik. Untuk memenuhi kebutuhan pembaruan hukum, maka dilakukan penataan kehidupan politik melalui keputusan kekuasaan negara. Dengan demikian, semakin baik sistem politik yang dianut oleh suatu Negara, maka semakin baik pula peluang pembaruan hukum Islam untuk ditetapkan sebagai hukum keluarga secara positif.

5. Pranata hukum, berfungsi untuk memberikan legitimasi yuridis pembaruan hukum Islam dalam hukum keluarga Indonesia. Sebagaimana diketahui bahwa konstitusi Negara (UUD 1945) memberikan legitimasi yang kuat bagi pembaruan hukum keluarga Islam untuk ditetapkan sebagai hukum nasional.

\section{Penutup}

Mengacu dari uraian yang telah dikemukakan di atas, ditarik simpulan sebagai berikut:

1. Pembaruan hukum Islam dalam konteks hukum keluarga Indonesia dipandang sebagai amanah konstitusi Negara untuk menggantikan produk-produk hukum kolonial Belanda yang masih berlaku dan untuk menggantikan beberapa produk hukum yang dipandang tidak sesuai dengan tuntutan perubahan.

2. Pembaruan hukum Islam dalam konteks hukum keluarga Indonesia meliputi empat kategori, yaitu; fikih, fatwa, yurisprudensi dan perundang-undangan.

3. Aspek-aspek yang terkait dengan pembahuruan hukum Islam dalam hukum keluarga Indonesia, antara lain: aspek materil, aspek metodologis, dan aspek metodologis.

Disadari sepenuhnya bahwa makalah ini masih jauh dari kesempurnaan, olehnya itu sumbang saran dan kritik konstruktif dari semua pihak menjadi kehormatan bagi penulis. 


\section{Daitar Pustaka}

Ali, Muhammad Daud, Hukum Islam dan Peradilan Agama : Kumpulan Tulisan, Cet. I; Jakarta : Raja Grafindo Persada, 1997

Anderson, J.N.D., Islamic Law in Modern World, alih bahasa oleh Machnun Husain dengan judul : Hukum Islam di Dunia Modern, Cet. I; Surabaya : Amar Press, 1991

Ash-Shiddiqy, Hasbi, Syariat Islam Menjawab Tantangan Zaman, Jakarta: Bulan Bintang, 1966

Bisri, Cik Hasan, Hukum Islam Dalam Tatanan Masyarakat Indonesia, Cet. I; Jakarta : Logos, 1998

Djatnika, Rahmat, Jalan mencari Hukum Islam Upaya Ke Arah Pemahaman Metodologi Ijtihad, Dalam, Amrullah Ahmad SF, Dimensi Hukum Islam Dalam Sistem Hukum Nasional, Cet. I; Jakarta : Gema Insani Press, 1996

Fuad, Mahsun, Hukum Islam Indonesia: dari Nalar Partisipatoris Hingga Emansipatoris, Cet. I; Yogyakarta: LKiS, 2005

Hanafi, Ahmad, Sejarah dan Pengantar Hukum Islam, Cet. IV; Jakarta : Bulan Bintang, 1986

Harahap, M. Hahya, Informasi Materi Kompilasi Hukum Islam : Mempositifkan Abstraksi Hukum Islam, dalam Cik Hasan Bisri (Peny.), Kompilasi Hukum Islam dan Peradilan Agama dalam Sistem Hukum Nasional, Cet. II; Jakarta : Logos Wacana Ilmu, 1999

al-Jauziyah, Ibnu Qayyim, I'lam al-Muwaqqiin an Rab al-Alamin, Juz III, Beirut: Dar al-Fikr, t. th.

Jazuli, A., Ilmu Fiqh: Sebuah Pengantar, Cet. I; Bandung: Orba Shakti, 1991

Mudzhar, Muh. Atho, Fatwa-Fatwa Majelis Ulama, Cet. I; Jakarta: INIS, 1993 
Rofiq, Ahmad, Pembaharuan Hukum Islam di Indonesia, Cet. I; Jakarta: Raja Grafindo Persada, 1995

Syaukani, Imam, Rekonstruksi Epistemologi Hukum Islam dan Relevansinya dengan Pembangunan Hukum Nasional, Cet. I; Jakarta: Raja Grafindo Persada, 2006

Wahid, Marzuki, dan Rumadi, Fikih Mazhab Negara, Cet. I; Yogyakarta: LkiS, 2001

Yafie, Ali, Fikih Sosial, Cet. I; Jakarta : Logos Wacana Ilmu, 1994. 